\title{
Serine/Threonine Protein Phosphatase Assays
}

\author{
Thomas McAvoy ${ }^{\star}$ and Angus C. Nairn ${ }^{\#}$ \\ *Laboratory of Molecular and Cellular Neuroscience, The Rockefeller University, New York, New \\ York 10021 \\ \#Department of Psychiatry, Yale University School of Medicine, New Haven, CT 06508
}

\begin{abstract}
Methods for assaying serine/threonine protein phosphatases are discussed. Three commonly used protocols are presented that employ either colorometric or radiometric assays. These methods can be used to assay a variety of preparations of serine/threonine phosphatases, from crude lysates to purified proteins. Strategies are discussed concerning the application of a particular protocol for a particular purpose. The assays discussed can be use in either a high throughput mode where simple comparison of activities can be compared, or in specific assays where kinetic data can be derived.
\end{abstract}

\section{UNIT INTRODUCTION}

Post-translational modification of proteins by protein phosphorylation is a common mechanism used for reversibly regulating signal transduction cascades and cellular physiology. Both protein kinases and protein phosphatases play important roles in determining the magnitude and duration of a signaling event. Protein kinases catalyze the transfer of a phosphate moiety from ATP to proteins and phosphatases act to remove this phosphate group by hydrolysis. There are three amino acids that are commonly modified by phosphorylation: serine, threonine, and tyrosine. Enzymes regulating dephosphorylation levels on these residues are roughly divided between two major groups, with those acting at serine and threonine being structurally and mechanistically distinct from those acting at tyrosine. This Unit describes protocols that are optimized for assays of serine/threonine protein phosphatases. See Mercan and Bennett (Current Protocols 2010 reference) for discussion of analysis of tyrosine protein phosphatases. Three basic protocols are described that utilize a small molecule, non-protein substrate (Protocol 1); a colorometric assay using a synthetic phospho-peptide (Protocol 2); and a radioactive release assay using a ${ }^{32} \mathrm{P}$-labeled protein substrate (Protocol 3). Strategies are discussed concerning which of these assays is more appropriate for a particular application.

\section{STRATEGIC PLANNING}

This unit describes several methods to assay for serine/threonine phosphatase activity in an in vitro system using purified substrates. The first and most important step is to choose the appropriate assay system and substrate based on the goal of the experiment and the materials that are available. This unit describes three different methods to assay a protein sample for protein serine/threonine phosphatase activity: colorimetric phosphatase assays using pnitrophenyl phosphate (pNPP) (Protocol 1) or malachite green (Protocol 2) and assays using ${ }^{32}$ P-labeled protein substrates (Protocol 3). In most circumstances, the ease of use of the simpler protocols (Protocols 1 and 2) is balanced against the additional work needed to 
examine more specific interactions of a particular protein phosphatase and a specific substrate (Protocol 3).

The small molecule substrate p-nitrophenyl phosphate (pNPP) is dephosphorylated by most protein phosphatases and is useful for a rapid colorimetric assay of total phosphatase activity in a sample. The use of a synthetic phospho-peptide and the malachite green assay may provide increased activity and some degree of specificity with minimal preparation. Studies requiring accurate kinetic information specific to a particular phosphatase will require production of a phosphorylated full-length protein substrate. In many situations, using a radio-labeled full-length protein substrate is preferred; however the more labor intensive process of producing large quantities of substrate and the ability to work with radionucleotides often make simpler colorimetric assays more attractive.

\section{BASIC PROTOCOL 1 - COLORIMETRIC ASSAY OF PROTEIN PHOSPHATASES USING p-NITROPHENYLPHOSPHATE}

This assay is widely used for detection of alkaline phosphatase activity in ELISA, but can be used in many instances where protein phosphatases are assayed. Because both acid and alkaline phosphatases act on pNPP, this assay is not routinely used with crude tissue extracts unless accompanied by the inclusion of selective inhibitors of specific serine/threonine protein phosphatases (see below) that can be used to examine the contribution of individual protein phosphatases to the overall tissue extract activity. Assays are typically performed in a 96-well format with colorimetric detection using a plate reader at $405 \mathrm{~nm}$.

\section{Materials}

p-nitrophenyl phosphate solution or tablets

1x colorimetric assay buffer (see Reagents and Solutions)

$5 \mathrm{~N} \mathrm{NaOH}$

Standard flat-bottomed 96-well microtiter plate

microplate reader capable of reading absorbance at $405 \mathrm{~nm}$

1. Dilute samples of protein phosphatase to $50 \mu \mathrm{l}$ in $1 \mathrm{x}$ colorimetric assay buffer in 96-well plate at room temperature.

2. Prepare $10 \mathrm{mM}$ pNPP substrate solution in $1 \mathrm{x}$ colorimetric assay buffer.

3. Add $50 \mu 1 \mathrm{pNPP}$ solution to each well at regular time intervals (10s).

4. Let reaction proceed for 10-45 min at room temperature (RT). Temperatures up to $37 o C$ can be used to shorten the reaction time.

5. Stop reaction by adding $20 \mu 15 \mathrm{~N} \mathrm{NaOH}$ using the same time interval used in step 3.

6. Tap side of plate gently several times to mix and incubate at RT for $30 \mathrm{sec}$.

7. Read absorbance at $405 \mathrm{~nm}$.

The molar extinction coefficient for pNPP is 18,000 M-1cm-1. The blank should be subtracted to account for any phosphate release occurring in the absence of phosphatase. 


\section{BASIC PROTOCOL 2 - COLORIMETRIC ASSAY OF PROTEIN PHOSPHATASES USING A SYNTHETIC PHOSPHO-PEPTIDE SUBSTRATE AND MALACHITE GREEN REAGENT}

In this non-radioactive dye based assay, the release of free phosphate from a synthetic phosphor-peptide is detected using the malachite green reagent, which can be read in 96well format with a colorimetric plate reader at $620 \mathrm{~nm}$. This assay is based on a complex that forms between inorganic phosphate and malachite green molybdate in acidic conditions. The use of a specific phospho-peptide substrate offers advantages in increased specificity over the pNPP assay. Compared to the ${ }^{32} \mathrm{P}$ labeled protein assay, it allows the study of a single phosphorylation site with minimal preparation, however, caution must be taken as the enzyme kinetic parameters often vary between assays using a phospho-peptide substrate and a full-length protein. This assay is usually appropriate for screening experiments where higher throughput is preferred over accuracy.

If a specific substrate phosphorylation site is to be studied, a phospho-peptide encompassing the site can often be synthesized for use in this assay. There are also many commercially available phospho-peptides that can be used that encompass a known site of phosphorylation in a particular protein. Peptides in the range of 6-20 amino acids have been used successfully. Although longer is often better so as to improve specificity, it is good to consult with the producer of your custom peptide to avoid sequences that may cause problems in solubility or yield. Quantitation of the phospho-peptide and determination of purity can be readily accomplished with mass spectrometric analysis.

It is essential that all measureable traces of phosphate contamination be removed from the sample to be tested. This can be checked in an experiment where all assay ingredients except phosphatase are examined compared to a phosphate standard curve. Prepare a standard curve using serial dilutions of a standard $1 \mathrm{mM}$ phosphate solution.

\section{Materials}

Synthetic peptide, $10 \mathrm{mM}$ stock solution dissolved in $\mathrm{ddH}_{2} \mathrm{O}$ and stored at $-20^{\circ} \mathrm{C}$

1x colorimetric assay buffer (see Reagents and Solutions)

Malachite green phosphate assay reagent or kit (widely available)

Phosphate standard, $1 \mathrm{mM} \mathrm{KH}{ }_{2} \mathrm{PO}_{4}$

Microtiter plate shaker (optional)

Standard flat-bottomed 96-well microtiter plate

Microplate reader capable of reading absorbance at $620 \mathrm{~nm}$ (or in 600-630 nm range)

Methods

1. Follow kit instructions to prepare a fresh working solution of the malachite green reagent, if needed.

2. Mix phosphopeptide and colorimetric assay buffer to make a $2 \mathrm{x}$ working solution. The necessary substrate concentration depends primarily on the $K_{m}$ of the reaction which can be determined in an independent experiment. Typically, a final peptide concentration of $200 \mu \mathrm{M}$ phosphopeptide is usually a good starting point for this type of assay. 
3. Add $20 \mu \mathrm{l}$ phosphatase sample diluted in $1 \mathrm{x}$ colorimetric assay buffer to wells of a 96-well plate. Include a phosphate standard curve and blank samples containing no phosphatase. Perform preliminary experiments to determine the linear range, usually 0.1-2 nmol phosphate.

4. Equilibrate all reagents for $10 \mathrm{~min}$ at RT.

5. Start the reaction by adding $20 \mu 12 \mathrm{x}$ working phosphopeptide substrate solution to the wells containing phosphatase samples.

6. Mix reagents by gently tapping the plate or using a microtiter plate shaker.

7. Allow the reaction to proceed for 20-30 min at RT.

8. Stop the reaction at the appropriate time by adding 50-100 $\mu 1$ malachite green working solution. Also add the solution to wells containing blanks and standards.

9. Let the plate sit for 10-15 $\mathrm{min}$ at RT to allow for color to develop.

10. Read plate at $620 \mathrm{~nm}$.

\section{BASIC PROTOCOL 3 - ASSAY OF PROTEIN PHOSPHATASES USING ${ }^{32}$ P- LABELED SUBSTRATES}

The classical method to measure the activity of protein phosphatases involves the use of purified protein substrates that are prelabeled with $\left[\gamma_{-}{ }^{32} \mathrm{P}\right]-\mathrm{ATP}$ (Collins and Sim 1998; Killilea, Cheng et al. 1998; MacKintosh and Moorhead 1999) The greatest advantage of this method is the ability to more accurately measure the kinetic parameters of a specific phosphatase reaction. This method also offers lower backgrounds and fewer problems with interfering compounds than colorimetric assays.

This assay method involves several steps. A sufficient quantity of a dephosphorylated substrate protein is first purchased or purified. It must then be ${ }^{32} \mathrm{P}$-labeled using a purified protein kinase in an in vitro phosphorylation reaction. The use of $\left[\gamma_{-}{ }^{33} \mathrm{P}\right]-\mathrm{ATP}$ is an acceptable alternative. Interfering free phosphate label should then be removed using desalting, dialysis, or washing (if the substrate is bound to an affinity matrix). Finally, the ${ }^{32} \mathrm{P}$-labeled substrate should be checked for the level of background (unincorporated) label and the amount of label incorporation (stoichiometry).

The standard substrate for measuring or comparing the activity of the serine/threonine phosphatases is Phosphorylase a, which is commercially available as Phosphorylase b (unphosphorylated form) in milligram to gram quantities. This protein is primarily labeled at one site using phosphorylase kinase in an in vitro phosphorylation reaction to produce Phosphorylase a. It can then be used as a broad specificity serine/threonine phosphatase substrate, especially for the study of PP1 and PP2A (see discussion of types of protein phosphatases below). It is often used in experiments to compare, for instance, the effect of an inhibitor on various purified protein serine/threonine phosphatases (see below). Other proteins that are commonly used as substrates include Mylein Basic Protein (MBP), Casein, and Histone H1. These proteins are useful for the assay of PP2B and PP2C (MacKintosh and Moorhead 1999) but typically phosphorylated on multiple sites by most common protein kinases, making them less useful for obtaining quality kinetic data.

Materials

1x labeled substrate assay buffer (see Reagents and Solutions)

${ }^{32} \mathrm{P}$-labeled substrate (see Supporting Protocol 1) 
Phosphatase solution

$1.5 \mathrm{ml}$ eppendorff-style tubes

$2.0 \mathrm{ml}$ screw-cap tubes

$20 \%$ aqueous Trichloroacetic acid (TCA) solution

Scintillation counter

Phosphatase inhibitor or activator (if needed)

\section{Methods}

1. Solution A [Substrate]- Dilute substrate to a $3 \mathrm{x}$ working solution $(30 \mu \mathrm{M})$ using $1 \mathrm{x}$ reaction buffer. $10 \mu \mathrm{l}$ of this solution should have $>50,000 \mathrm{cpm}$.

2. Solution B [Enzyme]- Dilute phosphatase in $1 \mathrm{x}$ reaction buffer.

3. Solution $\mathrm{C}$ [Inhibitors/Activators]- 3x solution of phosphatase inhibitor or activator in $1 \mathrm{x}$ reaction buffer.

4. In each tube, combine $10 \mu 1$ Solution B with $10 \mu$ l Solution C. Include tubes for blanks and total label added.

5. Warm all solutions to $30^{\circ} \mathrm{C}$ for $5 \mathrm{~min}$. A tray partially submerged in a gentlyshaking $30^{\circ} \mathrm{C}$ water bath is a good way to ensure temperature stability.

6. Start the reactions with $10 \mu 1$ Solution A with $10 \mathrm{sec}$ intervals between samples.

7. After $10 \mathrm{~min}$, stop the reaction in the same order and interval by the addition of 200 $\mu 1$ 10\% Trichloroacetic acid and brief vortexing.

8. Centrifuge samples at $15,000 \times \mathrm{g}$ for $10 \mathrm{~min}$.

9. Transfer $200 \mu \mathrm{l}$ of each supernatant to new $2.0 \mathrm{ml}$ screw cap tubes and seal them.

10. Place each tube inside a scintillation vial in the absence of scintillation fluid and count Cerenkov radiation.

\section{Supporting Protocol 1}

PREPARATION OF ${ }^{32}$ P-LABELED SUBSTRATE (PHOSPHORYLASE A)-This protocol can be performed in one day and is designed to produce $20 \mathrm{mg}$ of Phosphorylase a substrate, which should allow for the phosphatase measurement of several hundred samples. Other proteins, kinases, and their associated buffers can be substituted for the Phosphorylase $\mathrm{b}$ reaction components used here. Removal of excess label can also be performed using dialysis or ultrafiltration concentrating devices, however, use of desalting columns detailed here was found to be most efficient and convenient in terms of speed and containment of radioactive waste.

Materials: Phosphorylase b, $20 \mathrm{mg}$ protein supplied as lyophilized crystals (Sigma or Calzyme)

Phosphorylase Kinase, $1.4 \mathrm{mg}$ powder (Sigma)

10x Phosphorylase Kinase reaction buffer

(1 M Tris-HCl, pH 8.2, 1 M Glycerol-1-Phosphate, 1 mM CaCl $2,100 \mathrm{mM}$ Magnesium Acetate) 
ATP $10 \mathrm{mM}$

$\left[\gamma-{ }^{32} \mathrm{P}\right]-\mathrm{ATP}$ at $8000 \mathrm{mCi} / \mathrm{ml}$ (Perkin Elmer NEG-502A)

Desalting column for $2.5 \mathrm{ml}$ sample volumes (PD-10 column, GE biosciences)

Desalting column for $100 \mu \mathrm{l}$ sample volumes (NICK column, GE biosciences)

90\% saturated Ammonium Sulfate solution (66.2g Ammonium Sulfate in $100 \mathrm{~mL}$ aqueous solution)

Storage solution (50 mM Tris-HCl, pH 7.5, 0.1 mM EGTA, 1 mM DTT, 15 mM caffeine)

$15 \mathrm{ml}$ centrifuge tubes

$2 \mathrm{ml}$ screw cap tubes

\section{Methods}

1. Dissolve Phosphorylase $\mathrm{b}$ crystals and Phosphorylase kinase in $1.5 \mathrm{ml}$ water and add $400 \mu \mathrm{l} 10$ reaction buffer at RT in a $15 \mathrm{ml}$ tube. After $10 \mathrm{~min}$ of gentle mixing, centrifuge solution at $15,000 \times \mathrm{g}$ for 5 minutes and transfer supernatant to a new 15 $\mathrm{ml}$ tube. A large pellet indicates that the substrate is denatured and should not be used.

2. Mix $40 \mu 1$ of the $10 \mathrm{mM}$ ATP stock with $\left[\gamma_{-}{ }^{32} \mathrm{P}\right]$-ATP label. Calculate amount of radioactive label needed to give a final ratio of approximately $2000 \mathrm{cpm} / \mathrm{pmol}$ ATP. Check by making a 1/100 dilution and determining the cpm by Cerenkov counting or using liquid scintillation fluid. Be aware of the efficiency of the method and instrument you use and adjust your calculation accordingly.

3. Start the reaction by adding the ATP solution and water to bring the total volume to $2 \mathrm{~mL}$.

4. Incubate solution at $30^{\circ} \mathrm{C}$ for $1-2 \mathrm{hr}$.

5. Stop the reaction by adding the reaction directly to a PD-10 desalting column. After the solution is absorbed, carefully collect the desalted peak by adding additional water or buffer and collecting $0.5 \mathrm{ml}$ aliquots. Monitor protein content in each fraction using a Bradford assay. Pool labeled protein fractions in a $15 \mathrm{ml}$ centrifuge tube. Scaled-down reactions using less than $20 \mathrm{mg}$ starting material may not require this initial buffer exchange step.

6. Precipitate desalted proteins by adding an equal volume of $90 \%$ Ammonium Sulfate and let stand on ice for $30 \mathrm{~min}$.

7. Centrifuge the milky solution at $15,000 \times \mathrm{g}$ for $15 \mathrm{~min}$ at $4{ }^{\circ} \mathrm{C}$.

8. Resuspend pellet in $1 \mathrm{ml} \mathrm{45 \%} \mathrm{Ammonium} \mathrm{Sulfate} \mathrm{(2-fold?} \mathrm{dilution} \mathrm{of} \mathrm{90 \%}$ solution), transfer to $1.5 \mathrm{ml}$ tube, and let sit on ice $30 \mathrm{~min}$. This washes the saltedout proteins.

9. Centrifuge at $15,000 \times \mathrm{g}$ for $15 \mathrm{~min}$.

10. Remove supernatant and centrifuge $15,000 \times \mathrm{g}$ for $30 \mathrm{sec}$ to be able to remove the last traces of liquid. 
11. Completely resuspend pellet in $50 \mu 1$ storage solution. If the pellet does not completely dissolve, add more storage solution in $10 \mu \mathrm{l}$ increments followed by gentle mixing until the solution appears clear. Avoid the formation of bubbles.

12. Spin down the solution briefly and add the solution (approximately $100 \mu \mathrm{l}$ ) to a small-volume (NICK) desalting column pre-equilibrated with storage solution.

13. Push the sample through the column with $400 \mu \mathrm{L}$ water.

14. Collect desalted sample into a new tube by adding $400 \mu \mathrm{L}$ water, add glycerol to $10 \%$ final volume, and store in a shielded container at $4{ }^{\circ} \mathrm{C}$. Do not freeze phosphorylase as it will cause the protein to denature and precipitate.

15. Calculate the degree of phosphorylation (moles ${ }^{32} \mathrm{P}$ per mole protein) of the Phosphorylase a substrate by performing a protein assay of a small aliquot and Cherenkov counting. The A280 for a $1 \mathrm{mg} / \mathrm{ml}$ solution is 1.31. Radiolabeled substrate is usually good for several weeks until a significant portion of the label decays or the background level increases.

REAGENTS AND SOLUTIONS- $1 \mathrm{x}$ colorimetric assay buffer:

$20 \mathrm{mM}$ Tris, $\mathrm{pH} 7.5$

$5 \mathrm{mM} \mathrm{MgCl} 2$

1 mM EGTA

$0.02 \% \beta$-mercaptoethanol

$0.1 \mathrm{mg} / \mathrm{ml}$ bovine serum albumin (BSA)

$\underline{1 \mathrm{x} \text { labeled substrate assay buffer: }}$

$20 \mathrm{mM}$ Tris, $\mathrm{pH} 7.5$

$5 \mathrm{mM} \mathrm{MgCl} 2$

1 mM EGTA

$1 \mathrm{mM}$ DTT

$0.03 \%$ Brij-35

$0.3 \mathrm{mg} / \mathrm{ml}$ bovine serum albumin (BSA)

5 mM Caffeine (if using Phosphorylase)

(if needed) protease inhibitor cocktail (mini EDTA-free, Roche)

$5 \mathrm{mM} \mathrm{CaCl}_{2}$ (for PP2B only)

$100 \mu \mathrm{g} / \mathrm{ml}$ Calmodulin (for PP2B only) 


\section{COMMENTARY}

\section{Background Information}

Serine/threonine phosphatases are divided into two major gene families: the PPP family and the $\mathrm{Mg}^{2+}$-dependent PPM family (Andreeva and Kutuzov 2001). The major representatives of the PPP family, which account for a majority of serine/threonine dephosphorylation in eukaryotic cells, are PP1, PP2A and PP2B. There are multiple isoforms for each of the catalytic subunits of these enzymes. Moreover, these protein phosphatases are regulated by targeting subunits that localize the enzyme near specific cellular targets and influence their substrate selection at these sites (Virshup and Shenolikar 2009). The PPM class includes multiple isoforms of PP2C. Table 1 describes the major features of several of these phosphatases. Other less abundant serine/threonine phosphatases including PP4, PP5, PP6 and PP7, can be assayed by the methods described here.

Small molecule inhibitors are typically used in a titration assay to identify the relative contribution of inhibitor-sensitive phosphatases. Table 2 lists many inhibitors and their use for distinguishing between different phosphatase activities in an in vitro assay. Many of these small molecule phosphatase inhibitors can also be used effectively to study physiologic signaling pathways with in vivo studies, which are described in unit 18.10.

\section{Critical Parameters}

As mentioned above, prior to beginning experiments, an investigator should consider the utility of the different basic protocols, and their uses and limitations. Protocol 1 uses a nonpeptide substrate, pNPP, which can detect protein phosphatase activity but this is a nonselective substrate that will be dephosphorylated by serine/threonine, tyrosine, and nonprotein phosphatases. The method would be of little use for assays of crude tissue extracts, unless combined with selective inhibitors, which if effective might allow measurement of specific protein phosphatase activity by subtraction of the activity in the presence of inhibitor from the total activity. The method is however simple to set up and easy to carry out. In a case where, for example, purified phosphatases are available, protocol 1 may be useful for routine assays, and can be exploited in a high-throughput situation. Note though that the affinity of pNPP for substrate is very low $(\mathrm{mM} \mathrm{Km})$ compared to a natural phosphoprotein (typically $\mu \mathrm{M} \mathrm{Km}$ ), while the maximal catalytic activity (Vmax) can often approach that of a natural substrate.

Protocol 2 combines a non-radioactive, colorometric assay with the use of a synthetic phospho-peptide as substrate. The assay is easy to set up and carry out, offers the advantage that a peptide substrate is used, and also allows the investigator to relate the activity of a particular protein phosphatase to a single site of dephosphorylation. Limitations include the fact that there may be significant kinetic differences between the dephosphorylation of a particular site in a native protein and a short phospho-peptide that encompasses the site of interest. This likely results from the fact that the PPP and PPM enzymes often select substrates based on protein:protein interactions that occur outside of the immediate part of the polypeptide chain that includes the phosphorylated serine or threonine. In particular, PP1 does not exhibit high activity towards short phospho-peptides.

For Protocol 3, when designing a phosphatase experiment using a new purified protein as a substrate, the following issues should be considered:

- Choice of protein substrate:

$\circ \quad$ Quantity of substrate available

$\circ \quad$ Substrate purity 
○ Substrate solubility

- Availability of active labeling kinase

- Number of phosphorylation sites

- Extent of phosphate incorporation (stoichiometry)

The major protein serine/threonine phosphatases exhibit wide and often overlapping substrate specificities. It is not uncommon that more than one protein serine/threonine phosphatase dephosphorylates a single phosphorylation site. Distinguishing these activities in vitro can be accomplished using either small molecule inhibitors or specific protein inhibitory subunits.

Ideally, the highly purified protein substrate mimics a physiological substrate for the phosphatase and can be phosphorylated in vitro at only one site at a high level of stoichiometry. Proteins or protein fragments with purification tags (such as GST) may be useful for easily producing substrates, however proper controls must be used to ensure that the tag is not also phosphorylated.

Before beginning any work of this nature, ensure that all procedures involving radioactivity are done according to your specific institutional guidelines. Labeling milligram quantities of protein and conducting many assays can create a considerable amount of liquid and solid radioactive waste that must be planned for in advance and dealt with responsibly.

\section{Troubleshooting}

If a protein substrate is used, be aware that the presence of protease activity in the sample or enzyme preparation may produce misleading data. Assays involving a TCA precipitation step are especially susceptible to this error as short, digested peptides are often not efficiently precipitated. If the possibility of protease contamination exists, it is worthwhile to determine if the measured phosphatase activity is inhibited by specific phosphatase inhibitors, but not a mixture of protease inhibitors.

Other potential problems that might be encountered are summarized in Table 3.

\section{Anticipated Results}

For each Protocol, assay precision (variability) and linear range should be validated using serial dilutions of test phosphatase samples to ensure quality data. Minimally, replicates for each assay condition should be used. The lower limit of the assay is defined by the "blank" or substrate tested without active phosphatase. The upper limit of the assay is commonly defined by departure from steady state conditions and linearity due to substrate utilization or product inhibition. In the latter case, excess unphosphorylated substrate (product) competes with the phosphorylated substrate to limit the enzyme activity. To avoid this, substrates must first be prepared at a high stoichiometry of phosphorylation. Then, since unphosphorylated protein is formed as the phosphatase reaction proceeds, only initial rates of substrate dephosphorylation are used for the assay. As a general rule, initial rate measurement occurs only with activity data representing less than $30 \%$ of the total substrate be used, however it is recommended that a standard curve be constructed that can clearly define the linear range. During each experiment, it is important to monitor the quality of the substrate by including one or more samples of substrate processed without phosphatase ("blanks") and a sample measuring total substrate added ("total"). In this way, unknown samples with activities higher than the $30 \%$ rule or outside the linear range can be quickly identified, diluted, and re-run. 
Protocols 1 and 2 are colorometric assays which if carried out under these optimal conditions should generate simple datasets that can be converted into moles of phosphate generated (compared to a standard curve) by a known amount of tissue sample or purified protein phosphatase. Protocol 3 will generate data related to radioactive content which can also be converted into moles of phosphate through calculation of the specific activity of the ${ }^{32} \mathrm{P}$-ATP, and knowledge of the substrate concentration and stoichiometry of phosphorylation of one or more sites. If appropriate dilutions of substrate are used, and linear assay conditions are maintained, kinetic data can be derived from data generated by each protocol.

\section{Time Considerations}

The amount of time needed to prepare for the described phosphatase assays varies greatly and can be a major factor when deciding which assay system to use. pNPP requires very little preparation time and the malachite green assay only requires the synthesis (1-4 weeks) or purchase of a phosphopeptide substrate. Preparing a new full-length protein substrate for ${ }^{32} \mathrm{P}$-labeling may require many weeks to optimize. The kinase labeling reaction and removal of background label described here can be performed in one day. Be aware of the half-life of the labeled substrate so that the necessary assays can be completed before the label has decayed beyond its usefulness.

\section{LITERATURE CITED}

Andreeva AV, Kutuzov MA. PPP family of protein Ser/Thr phosphatases: two distinct branches? Mol Biol Evol. 2001; 18:448-452. [PubMed: 11230548]

Cohen PT. Protein phosphatase 1--targeted in many directions. J Cell Sci. 2002; 115:241-256. [PubMed: 11839776]

Collins E, Sim AT. Regulation of neuronal PP1 and PP2A during development. Methods Mol Biol. 1998; 93:79-102. [PubMed: 9664529]

Killilea SD, Cheng Q, et al. Protein phosphatase type 1 and type 2A assays. Methods Mol Biol. 1998; 93:23-33. [PubMed: 9664524]

Lu G, Wang Y. Functional diversity of mammalian type 2C protein phosphatase isoforms: new tales from an old family. Clin Exp Pharmacol Physiol. 2008; 35:107-112. [PubMed: 18197890]

MacKintosh, C.; Moorhead, GB. Assay and purificatio nof protein serine/threonine phosphatases. In: Hardie, DG., editor. Protein Phosphorylation: A Practical Approach. Oxford: Oxford University Press; 1999. p. 153-181.

Rusnak F, Mertz P. Calcineurin: form and function. Physiol Rev. 2000; 80:1483-1521. [PubMed: 11015619]

Shibasaki F, Hallin U, et al. Calcineurin as a multifunctional regulator. J Biochem. 2002; 131:1-15. [PubMed: 11754729]

Swingle M, Ni L, et al. Small-molecule inhibitors of ser/thr protein phosphatases: specificity, use and common forms of abuse. Methods Mol Biol. 2007; 365:23-38. [PubMed: 17200551]

Virshup DM, Shenolikar S. From promiscuity to precision: protein phosphatases get a makeover. Mol Cell. 2009; 33:537-545. [PubMed: 19285938]

Wang B, Zhang P, et al. Recent progress on the structure of Ser/Thr protein phosphatases. Sci China C Life Sci. 2008; 51:487-494. [PubMed: 18488168]

Xu Y, Xing Y, et al. Structure of the protein phosphatase 2A holoenzyme. Cell. 2006; 127:1239-1251. [PubMed: 17174897] 
Table 1

Major features of the common protein serine/threonine phosphatases

\begin{tabular}{|l|l|l|l|}
\hline Family & Common name & Regulation & References \\
\hline \multirow{3}{*}{ PPP } & Protein Phosphatse 1 (PP1) & activity regulated by targeting/inhibitory subunits & (Cohen 2002) \\
\cline { 2 - 4 } & Protein Phosphatase 2A (PP2A) & $\begin{array}{l}\text { Heterotrimer of A/B/C subunits; activity B subunit } \\
\text { and C subunit methylation regulates }\end{array}$ & $\begin{array}{l}\text { (Xu, Xing et al. 2006; Wang, Zhang et } \\
\text { al. 2008) }\end{array}$ \\
\cline { 2 - 5 } & $\begin{array}{l}\text { Protein Phosphatase 2B (PP2B), } \\
\text { Calcineurin }\end{array}$ & Ca2+/Calmodulin & $\begin{array}{l}\text { (Rusnak and Mertz 2000; Shibasaki, } \\
\text { Hallin et al. 2002) }\end{array}$ \\
\hline PPM & Protein Phosphatase 2C (PP2C) & Isoform specific mechanisms & (Lu and Wang 2008) \\
\hline
\end{tabular}


Table 2

Use of commonly used serine/threonine phosphatase inhibitors for in vitro assays

\begin{tabular}{|l|l|}
\hline Inhibitor/Condition & Use \\
\hline Microcystin-LR, Calyculin-A, Nodularin, Tautomycin & Potent inhibitors of both PP1 and PP2A (Swingle, Ni et al. 2007) \\
\hline Okadaic Acid, Fostriecin & $\begin{array}{l}\text { Potent inhibitors of PP2A; used to differentiate PP2A activity from PP1 } \\
\text { (Swingle, Ni et al. 2007) }\end{array}$ \\
\hline Ca2+ removal with excess EGTA & Prevents the activation of PP2B (calcineurin) by Calcium/Calmodulin \\
\hline Mg2+ removal with excess EDTA & Inhibits PP2C activity \\
\hline $\begin{array}{l}\text { PP1 inhibitory proteins (pT34-DARPP32, pT35-Inhibitor-1, } \\
\text { inhibitor-2) }\end{array}$ & Specific inhibition of PP1 \\
\hline
\end{tabular}


Table 3

Commonly encountered problems.

\begin{tabular}{|l|l|l|}
\hline Problem & Possible Cause & Solution \\
\hline $\begin{array}{l}\text { High Background (high signal with } \\
\text { no added phosphatase) }\end{array}$ & $\begin{array}{l}\text { Interfering substances present (malachite green } \\
\text { assay) } \\
\text { Insufficient removal of unincorporated label } \\
\text { (32P- labeled substrates) } \\
\text { Protease contamination ( }{ }^{32} \mathrm{P} \text { - labeled } \\
\text { substrates) } \\
\text { Phosphatase contamination of substrate stock } \\
\text { solution }\end{array}$ & $\begin{array}{l}\text { Remove trace amounts of phosphate from assay } \\
\text { buffers/reagents } \\
\text { Perform extra desalting or dialysis step to remove } \\
\text { unincorporated label } \\
\text { Add protease inhibitors to prevent substrate } \\
\text { hydrolysis }\end{array}$ \\
$\begin{array}{ll}\text { Prepare new substrate } \\
\text { labeled substrates) }\end{array}$ & $\begin{array}{l}\text { Ensure proper storage conditions. Prepare new } \\
\text { substrate using new lot of protein }\end{array}$ \\
\hline $\begin{array}{l}\text { Expected phosphatase activity is } \\
\text { not detected }\end{array}$ & Phosphatase is missing or inactivated & $\begin{array}{l}\text { Use a positive control phosphatase or standard curve } \\
\text { to check assay } \\
\text { Examine reaction mix for necessary cofactors }\end{array}$ \\
\hline $\begin{array}{l}\text { Cloudy precipitate (malachite } \\
\text { green assay) }\end{array}$ & Activators not present & $\begin{array}{l}\text { Identify and remove incompatible metals, phosphate, } \\
\text { detergents }\end{array}$ \\
\hline $\begin{array}{l}\text { Weak signal } \\
\text { Interfering substances present }\end{array}$ & Phosphatase too dilute & $\begin{array}{l}\text { Increase amount of phosphatase or increase the } \\
\text { assay time }\end{array}$ \\
\hline
\end{tabular}

